\title{
Monitoring Three Plasmopara halstedii Resistance Genes in Iranian Sunflower Inbred Lines
}

\author{
Masood Soltani Najafabadi *, Raha Abedini, Hassan Eskandari, Rahim Mehrabi \\ Seed and Plant Improvement Institute (SPII), Karaj, Iran \\ *Corresponding author: Masood Soltani Najafabadi, Seed and Plant Improvement Institute (SPII), Karaj, Iran. Tel: +98-26336703771, Fax: \\ +98-26336702051, E-mail: m.soltani@spii.ir
}

Received: December 29, 2014; Revised: March 29, 2015; Accepted: April 26, 2015

\begin{abstract}
Background: Downy mildew caused by Plasmopara halstedii is a devastating disease in sunflower worldwide. Several dominant resistance genes designated as $P l$ have been identified and linked molecular markers have been demonstrated. However, no information on theresistance genes is available forIranian lines.

Objectives: The presence of three map-based molecular markers previously proved to be linked to different resistance genes were evaluated in sunflower inbred lines.

Materials and Methods: Using PCR-based and CAPS molecular markers, 26 sunflower inbred lines with different responses to $P$. halstedii race 100 were used to detect the presence of three resistance loci including $P l_{1}, P l_{6}$ and $P l_{13}$ within the lines.

Results: Molecular marker linked to $\mathrm{Pl}_{13}$ was present in some of the sunflower lines but was not correlated with the phenotypic reaction of the lines to race 100. Despite the use of three markers linked to $\mathrm{Pl}_{6}$, PCR failed to amplify any corresponding product. This data may suggest that none of the genotypes possessed $P l_{6}$ locus. $P l_{l}$-linked cleaved amplified polymorphic sequences (CAPS) were present in several resistance lines and effectively differentiated susceptible and resistant sunflower lines.

Conclusions: Applicability of molecular markers in breeding programs revisited in disease management.

Keywords: CAPS; Downy mildew; Molecular marker; PCR; $P l_{l}$ locus
\end{abstract}

\section{Background}

Downy mildew of sunflower caused by an oomycete, Plasmopara halstedii (Farl.) Berl. etde Toni, is a widespread destructive plant disease worldwide (1). Yield losses under conductive environmental conditions can be high and reported to be up to $50 \%$ (2). The disease first was reported in USA in 1888 (3) and subsequently was observed in Europe in 1960 (4). The rapid spread of the disease during the last decades in Europe has led to a serious concern, threatening sunflower production (4). The causal agent of the disease was subjected to quarantine regulation in European Union since 1992 (4). Many approaches have been used to minimize the effects of the pathogen, including the use of fungicides and use of resistant genotypes. Under favorable conditions, application of systemic fungicides has been a common practice to control the disease. Nevertheless, extensive fungicide application impose high selection pressure on the pathogen populations leading to the emergence of fungicide resistance strains that eventually compromise effective disease control $(5,6)$. Therefore, employment of resistant genotypes is by far the most cost-effective and environmentally-safe strategy to control the disease. Rapid spread and high population dynamic of causal agent of the disease (4) highlights the need that sunflower producing countries equip their sunflower germplasm with different resistance genes. To this aim, screening of sunflower genotypes for resistance to the disease is required prior to their release in high risk growing regions.

Existence of physiologic races in $P$. halstedii is evident in many reports. Similar to many plantpathogen interactions, sunflower- $P$. halstedii interaction follows the gene-for-gene model (7). Up to now, at least 35 races from different parts of the world have been reported (8). Nomenclature of the races is based on their reactions to a set of differential lines, which are lines possessing different resistance genes and show differential responses to specific races (9). To 
date, a number of dominant genes designated as $\mathrm{Pl}$, have been proven to confer complete resistance to the pathogen in sunflower cultivars or their wild relatives (10). $P l_{1}$ was the first resistance gene identified in sunflower that provides resistancetorace100 (11). Several otherresistance genes have been identified and introduced to sunflower cultivars conferring resistance against different physiological races $(12,13,14)$. $\mathrm{Pl}_{2}$ confers resistance to race 300 (15). $\mathrm{Pl}_{3}$ and $\mathrm{Pl}_{4}$ were designated independently, but it was shown that they are equal to $P l_{1}$ and $P l_{2}$, respectively $(11,16) . P_{5}$ shows resistance to race 700 (17). $\mathrm{Pl}_{6}, \mathrm{Pl}_{7}$, and $\mathrm{Pl}_{8}$ confer resistanceagainst races $100,300,310,330$, and $700(18,19)$. Resistance to races 310,330 , and 300 is conferred by $P l_{9}, P l_{10}$, and $P l_{11}$, respectively (19). It has been found that $P l_{12}$ provides resistance against races 100,300 , and $700(12) . P l_{13}$ was also identified as a locus conferring resistance to races $300,700,730$, and 770 (20). The recent identified resistance gene, $P l_{14}$, confers resistance to race 730 (14). Although, several lines of evidence shows that $P l$ genes might have the coiled coils-nucleotide binding site-leucinerich repeat (CC-NBS-LRR) signature, so far none of the $P l$ genes are cloned $(21,13,22)$. Nevertheless, tightly linked molecular markers to a few $P l$ loci have been previously reported (23). For instance, toll/interleukin1 receptors-NBS-LRR classes of plant resistance genes were used to develop markers that are linked to $\mathrm{Pl}_{6}$ locus. Furthermore, CAPS markers linked to $\mathrm{Pl}_{6}$ was also developed (24). Two full length sequences belonging to CC-NBS-LRRclasses of plant resistance genes were cloned and their subsequent primers were designed to tag $P l_{5} / P l_{8}$ region (13). CAPS molecular marker linked to $P l_{l}$ locus was identified through cloning of candidate resistance genes belonging to NBS superfamily of genes (25). These markers have been successfully used by many research groups as a fast and reliable technique to screen sunflower genotypes.

Despite the fact that downy mildew is the major sunflower disease in Iran, limited information is available on the presence of physiological races as well as the presence or absence of resistance genes within cultivated sunflower genotypes. Recently, $P$. halstedii race 100 was identified as the dominant race infecting sunflower in Iran (26). The responses of several sunflower inbred lines to this race were also evaluated and several resistant genotypes were identified (26). The race identification and germplasm screening to $P$. halstedii have been performed using whole seedling immersion in zoospore suspension. Although the method is sensitive and accurate, it is cost effective, time-consuming and requires high experience to perform the experiment. Moreover, screening of $\mathrm{F}_{2}$ segregation populations using inoculation assays would eliminate some susceptible individuals with other useful traits. These limitations encourage breeders to take the advantages of molecular markers linked to disease resistance genes. In this study, we used previously published molecular markers linked to $P l_{1}, P l_{6}$ and $P l_{13}$ to screen the available sunflower genotypes in Iran.

\section{Materials and Methods}

\subsection{Assessment of Sunflowere Resistance to P. halste- dii}

Sunflower inbred lines (26 lines), were provided by Oil Seed Department, Seed and Plant Improvement Institute (SPII; Table 1). They are highly inbred lines,

Table 1. Name and responses of the sunflower lines to $P$. halstdiirace 100 used in this study

\begin{tabular}{|c|c|c|c|}
\hline No. & Line name & $\begin{array}{l}\text { Response to } P \text {. halst- } \\
\qquad i^{*}\end{array}$ & Line type \\
\hline 1 & SUN21 & resistant & restorer line \\
\hline 2 & SUN25 & resistant & restorer line \\
\hline 3 & SUN27 & resistant & restorer line \\
\hline 4 & SUN 31 & resistant & restorer line \\
\hline 5 & SUN36 & resistant & restorer line \\
\hline 6 & SUN37 & resistant & restorer line \\
\hline 7 & SUN38 & resistant & restorer line \\
\hline 8 & SUN41 & resistant & restorer line \\
\hline 9 & SUN45 & resistant & restorer line \\
\hline 10 & SUN47 & resistant & restorer line \\
\hline 11 & SUN48 & resistant & restorer line \\
\hline 12 & SUN20 & susceptible & B-line** \\
\hline 13 & SUN23 & susceptible & B-line \\
\hline 14 & SUN28 & susceptible & B-line \\
\hline 15 & SUN30 & susceptible & B-line \\
\hline 16 & SUN32 & susceptible & B-line \\
\hline 17 & SUN33 & susceptible & B-line \\
\hline 18 & SUN39 & susceptible & B-line \\
\hline 19 & SUN44 & susceptible & B-line \\
\hline 20 & SUN100 & susceptible & B-line \\
\hline 21 & SUN102 & susceptible & B-line \\
\hline 22 & SUN104 & susceptible & B-line \\
\hline 23 & SUN124 & susceptible & B-line \\
\hline 24 & SUN128 & susceptible & B-line \\
\hline 25 & SUN130 & susceptible & B-line \\
\hline 26 & SUN139 & susceptible & B-line \\
\hline
\end{tabular}

*Their responses have been previously evaluated using whole seedling immersion (Rahmanpour, personal communication) **B-line stands for maintainer line 
which have been produced by at least 20 rounds of selfing. The genotypes were previously evaluated for resistance to $P$. halstedii race 100 using whole seedling immersion method (Personal communication with Rahmanpur (27). Germinated seeds (2-3 days seedlings) were immersed in pathogen zoospore suspension.The seedlings were cultivated in humid and dark green house and the plantlets were evaluatedfor the resistance after two weeks (Table 1).

\subsection{Molecular Marker Analyses}

The oldest leaf at five-leaf stage was cut andsnapfrozen in liquid nitrogen. Genomic DNA was extracted according to previously described procedure (28). Integrity of the extracted DNA was checked using 1\% $(\mathrm{w} / \mathrm{v})$ agarose gel electrophoresis. PCR reactions were performed using primer pairs for $\mathrm{Pl}_{6}, \mathrm{Pl}_{13}$ and $\mathrm{Pl}_{1}$
(Table 2). PCR programs and ingredients were according to the earlier reports $(20,23,25)$. Briefly, PCR reactions were performed in $20 \mu \mathrm{L}$ containing $30 \mathrm{ng}$ sunflower genomic DNA, $2 \mu \mathrm{L} 10 \times \mathrm{PCR}$ buffer, 0.5 $\mathrm{mM}$ dNTPs, $0.5 \mu \mathrm{M}$ of each primer, $3.75 \mathrm{mM} \mathrm{MgCl}_{2}$ and $1 \mathrm{U} \mathrm{Taq}$ DNA polymerase (CinnaGen, Iran). The PCR conditions were $95^{\circ} \mathrm{C}$ for $4 \mathrm{~min}$, followed by 35 cycles of $94^{\circ} \mathrm{C}$ for $30 \mathrm{~s}, 52^{\circ} \mathrm{C}$ for $30 \mathrm{~s}$ and $72^{\circ} \mathrm{C}$ for 30 to 90s (according to the expected fragment size), plus a final extension at $72^{\circ} \mathrm{C}$ for $3 \mathrm{~min}$. Cleaved amplified polymorphic sequences (CAPS) analysis was performed according to previously described method (25) using restriction enzyme Tsp509I (Fermentas, London). DNA fragments were separated on $2 \%(\mathrm{w} / \mathrm{v})$ agarose gel, stained with ethidium bromide and visualized using a UV trans-illuminator. All the above steps were repeated twice.

Table2. Polymorphism and PIC values of ISSR and RAPD markers used for genetic diversity of 34 Pyrenophera triticirepentis isolates

\begin{tabular}{lcccc}
\hline Name & Forward (5' to 3') & Reverse (5' to 3') & Linked to & Reference \\
\hline Hap1 & GGTAATGGCTGTTGAATTTATGGAGC & AGCATGATCCGGCTAGAGCCTTCTA & PI6 & $(21)$ \\
Hap2 & GTCTACTACATGGTTTCCGTTTTC & TGCTTCTTCCTTCTATCTCACTC & PI6 & $(21)$ \\
Hap3 & GTTTGTGGATCATCTCTATGCG & TGCTTCTTCCTTCTATCTCACTC & PI6 & $(21)$ \\
STS10D6 & AACTACGACCCACAAAAGGACAAG & TTAGACCAGGGCCCAACAAAC & PI13 & $(18)$ \\
4W2 & ATGCGGAAATCTCTCACC & GACAGCCTCGTCTTGTGA & PI1 & $(23)$ \\
\hline
\end{tabular}

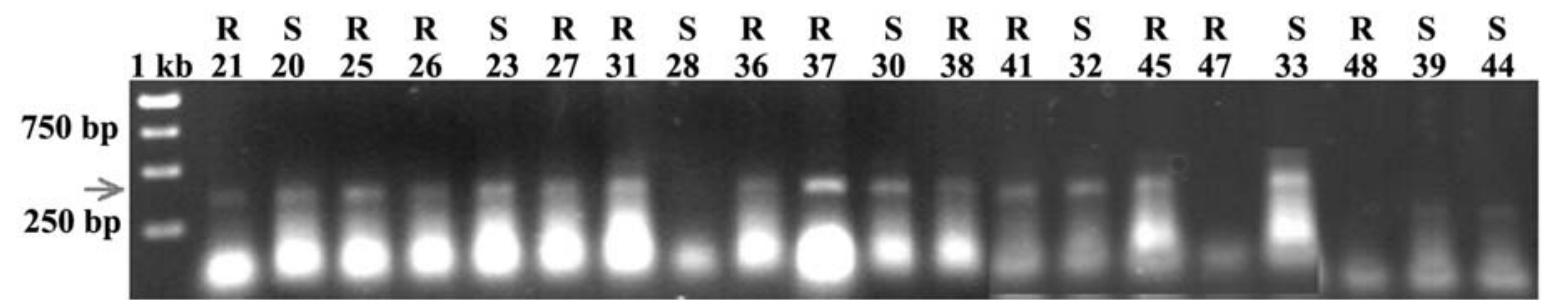

Figure 1. ThePCR profile of $P l_{13}$-linked marker (indicated by arrow) using the DNA of 20 sunflower inbred lines as template in PCR reaction. The genotype codes and their reactions to P. halstediirace 100 are presented on the top of PCR panel. $\mathrm{R}$ and $\mathrm{S}$ indicate resistant and susceptible lines, respectively

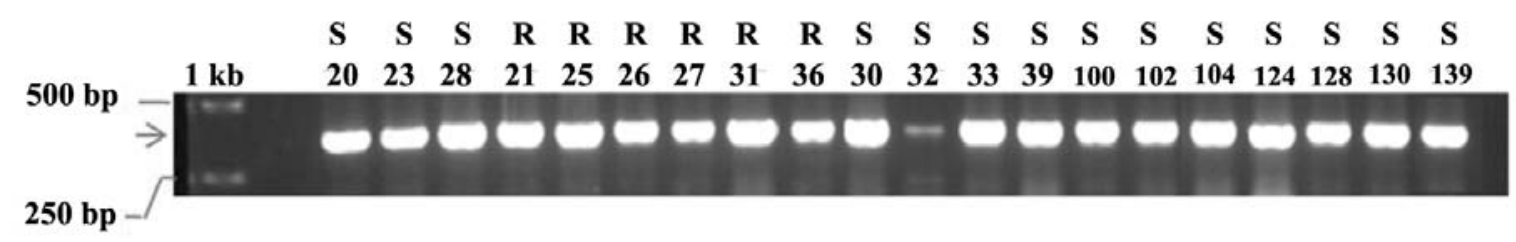

Figure 2. The PCR products of $P l_{1}$-linked locus, with the expected size of 370 bp as indicated by arrow, using the DNA of 20 sunflower inbred lines as template in PCR reaction. The genotype codes and their reactions to $P$. halstediirace 100 are presented on the top of PCR panel. R and S indicate resistant and susceptible lines, respectively 


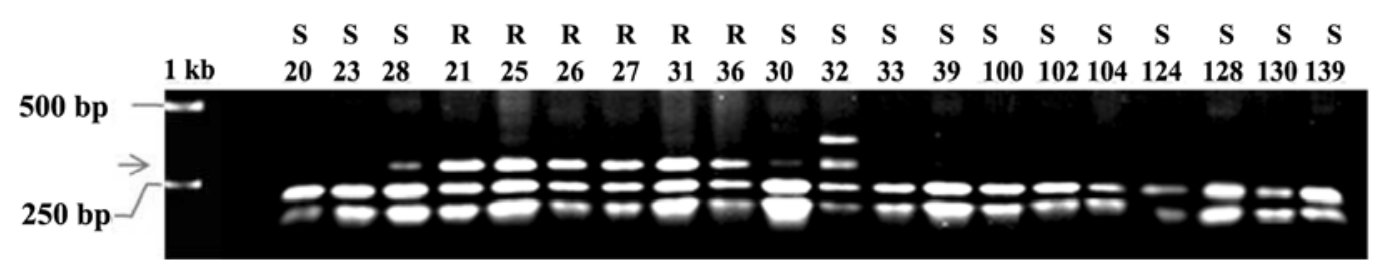

Figure 3. The cleavage pattern of PCR products presented in Figure 3. The products were digested using Tsp509I. The arrow indicates a band representing 276 bp resistance marker as described previously (23)

\section{Results}

DNAs from sunflower inbred lines with different responses to $P$. halstedii race 100 were used as template in PCR reactions using primer pair STS10D6 previously reported to serve as tightly linked to locus $P l_{13}$. A PCR fragment ranging in size from 250 to 500 bp was amplified in almost all lines $(n=20$; Figure 1$)$. The DNA fragment was absent in one susceptible and two resistant lines. Thus, this marker could not dissect the resistant and susceptible lines as differentiated by race 100. Primer pairs Hap1, Hap2, and Hap3 were used to amplify markers linked to $\mathrm{Pl}_{6}$. No DNA fragments (data are not shown) with the expected sizes ranging from 500 to $3000 \mathrm{bp}$ were amplified as reported (23). This mayindicate that none of the genotypes possessed $\mathrm{Pl}_{6}$ locus. PCR amplification using primer pair 4W2, used to amplify marker linked to $P l_{l}$, had resulted in a band of $370 \mathrm{bp}$ in size (25). As expected, the band was monomorph among all tested lines (Figure 2). PCR reactions were treated with restriction enzyme Tsp509I and separated on a $1.5 \%(\mathrm{w} / \mathrm{v})$ agarose gel (Figure 3). Digestion of PCR products resulted in two monomorphic bands below $250 \mathrm{bp}$ for all sunflower lines regardless of their reactions to $P$. halstedii. In addition to these two bands, all six resistant lines contained a sharp band with the size of $276 \mathrm{bp}$ as reported previously (25). Only two exceptions were observed among all lines, including the susceptible line \#28 that had a banding pattern similar to resistant lines and line \#32 that had an extra band with the approximate size of $370 \mathrm{bp}$.

\section{Discussion}

Employing molecular markers, either gene-based or map-based markers, efficiently accelerated breeding (29). Molecular markers have been widely used to monitor resistant genes in many species $(30,31,32$, $33,34,35)$ and most importantly in the early generation testing $(36,37)$. In this study, the presence of molecular markers linked to three $P l$ loci was investi- gated using PCR-based method. DNAs from sunflower inbred lines with different responses to $P$. halstedii race 100 were used as template in PCR reactions using primer pair STS10D6 previously reported to serve as tightly linked to $P l_{13}$ locus. Results showed that Iranian genotypes possess markers linked to $P l_{13}$ that can serve as a resistance gene against races 300 , 700,730 , and 770 in the future (20). As expected there was no correlation between the phenotypic reactions of these genotypes to $P$. halstedii race 100 and the presence of this marker in the genotypes. However our results revealed that these genotypes still could be sources of resistance to other races other than race 100 .

$\mathrm{Pl}_{6}$ was another locus that was investigated using three different markers. No PCR amplification product was observed in any of the genotypes tested in this study. It is reported that all of these markers are STSbased markers and, therefore, lack of these markers in Iranian lines might be a real reflection of lacking $\mathrm{Pl}_{6}$ resistance gene. Thus, to avoid the possible outbreak of the disease under Iranian growing conditions, breeding efforts must be made to incorporate $\mathrm{Pl}_{6}$ resistance gene into Iranian sunflower lines.

The primer pair 4W2 was used to amplify the marker linked to $P l_{1}$ locus. The amplified band with the approximate size of $370 \mathrm{bp}$ appeared to be monomorph among all the tested lines. Nevertheless, single-stranded conformational polymorphism (SSCP) analysis has been used to determine the possible complexity of the resulting band (25). The results showed that $4 \mathrm{~W} 2$ primers bind to multiple sites in the NBS regions in susceptible and resistant lines leading to amplification of a single band with approximate size of $370 \mathrm{bp}$ that consists of several different DNA amplicons (25). They showed that treating the PCR products with $T s p 509$ I would lead to three bands $(88,93$, and $188 \mathrm{bp})$ in susceptible lines while it generates four bands $(88,93,188$, and $276 \mathrm{bp})$ in resistant lines (25). In our experiment, we observed two monomorphic bands in all sunflower lines. The lowest band was con- 
sisted of two DNA fragments (88 and $93 \mathrm{bp}$ ) that were not separated due to approximate similar sizes and the second band with the size of $188 \mathrm{bp}$. In resistant lines, a $276 \mathrm{bp}$ band was observed that was indicator of resistant lines. Line \#32 had an extra band similar to undigested band (370 bp), which may represent partial digestion, a phenomenon observed when the digestion inhibitors are presented in the reactions. Another exception was line \#28 (susceptible line) that had a banding pattern similar to resistant lines. Because the same result was obtained when the experiment repeated, we concluded that maybe line, \#28, incorrectly been scored during phenotypic evaluation and might have a resistance response to $P$. halstedii race 100 . Alternatively, it is possible that the marker used to differentiate the resistant and susceptible lines is not completely linked to $P l_{1}$ locus and thus some rare exceptions can be present in marker-assisted selection process. Overall, presence or absence of the band with size about 276 bp in sunflower lines might be used to differentiate the resistant and susceptiblelines to $P$. halstedii race 100 .

In this study we used molecular markers to track loci conferring resistance to $P$. halstedii, and compared with the phenotypic reaction of sunflower lines to race 100. Our data showed that molecular markers can be efficiently used in screening and breeding programs. Good correlation between the presence of markers linked to resistance loci and their phenotypic reactions to pathogen justify implementation of these markers in marker-assisted selection programs. Our data suggest that application of molecular markers can facilitate breeding programs towards disease management.

\section{Acknowledgments}

The work was supported by SPII under the grant number 2-03-03-89170.

\section{References}

1. Roeckel-Drevet P, Tourvieille J, Gulya TJ, Charmet G, Nicolas P, LabrouheDT.Molecular variability of sunflower downy mildew, Plasmopara halstedii, from different continents. Can J Microbiol. 2003;49(8):492-502.

2. Sackston WE. Downy mildew of sunflower. In: Spencer DM, editor. The Downy Mildews.London: Academic Press; 1981;p $.545-575$.

3. Sedlarova M, Trojanova Z, Lebeda A. Distribution and harmfulness of Plasmopara halstedii on sunflower in the Czech Republic. Plant Protect Sci. 2013;49(1):1-10.

4. Delmotte F, Giresse X, Richard-Cervera S, M'baya J, VearF, Tourvieille J, Walser P, de Labrouhe DT. Single nucleotide polymorphisms reveal multiple introductions into France of Plasmopara halstedii, the plant pathogen causing sunflower downy mildew. Infect Genet Evol. 2008;8(5):534540. DOI: 10.1016/j.meegid.2008.02.012.

5. Albourie JM, TourvieilleJ,DeLabrouhe DT. Resistance to metalaxyl in isolates of the sunflower pathogen Plasmopara halstedii. Eur J Plant Pathol. 1998;104(3):235-242. DOI: 10.1023/A:1008691123239.

6. Molinero-Ruiz L, Domínguez J, Melero-Vera JM. Evaluation of Spanish isolates of Plasmopara halstedii for tolerance to metalaxyl. Helia. 2000;23(33):33-38.

7. Vear F, Gentzbittel L, Philippon J, Mouzeyar S, Mestries E, Roeckel-Drevet P, Labrouhe DT, Nicolas P. The genetics of resistance to five races of downy mildew (Plasmopara halstedii) in sunflower (Helianthus annuus L.). TheorAppl Genet. 1997;95(4):584-589. DOI: 10.1007/s00 1220050599.

8. Gulya TJ. Distribution of Plasmopara halstedii races from sunflower around the world. In proceeding of the II International downy mildew symposium, Palcky University in Olomouc and JOLA, Czech Republic. 2007; p.135-142.

9. LabrouheDT, Gulya TJ. New nomenclature of races of Plasmopara halstedii (sunflower downy mildew).In: Proceeding of $15^{\text {th }}$ International Sunflower Conference, Toulous, France. 2000;p. 61-65.

10. Miller J. Update on inheritance of sunflower characteristics. In: Proceeding of $13^{\text {th }}$ International Sunflower Conference, Pisa Italy. 1992;p.905-945.

11. Zimmer DE, Kinman ML. Downy mildew resistance in cultivated sunflower and its inheritance. Crop Sci. 1972;12(6):749-751. DOI: 10.2135/cropsci1972.0011183X 001200060009x

12. Rahim MM, Jan CC,Gulya TJ. Inheritance of resistance to sunflower downy mildew races 1,2 and 3 in cultivated sunflower. Plant Breed.2002;121(1):57-60. DOI: 10.1046/j. 1439-0523.2002.00680.x

13. Radwan O, Bouzidi MF, Nicolas P, Mouzeyar S. Development of PCR markers for the P15/P18 locus for resistance to Plasmopara halstedii in sunflower, Helianthus annuus L. from complete CC-NBS-LRR sequences. Theor Appl Genet. 2004;109(1):176-185. DOI: 10.1007/s00122-004-1613-0.

14. Bachlava E, Radwan OE, Abratti G, Tang S, Gao W, Heesacker AF, Bazzalo ME, Zambelli A, Leon AJ, Knapp SJ. Downy mildew (Pl (8) and Pl (14)) and rust (R (Adv)) resistance genes reside in close proximity to tandemly duplicated clusters of non-TIR-like NBS-LRR-encoding genes on sunflower chromosomes 1 and 13. Theor Appl Genet. 2011;122(6):12111221. DOI: $10.1007 / \mathrm{s} 00122-010-1525-0$.

15. Fick GN, Kinman ML, Zimmer DE. Registration of RHA-273 and RHA-274 sunflower parental lines. Crop Sci. 175;15(1):106. DOI: 10.2135/cropsci1975.0011183X 001500 $100052 x$.

16. Zimmer DE. Physiological specialization between races of Plasmopara halstedii in America and Europe. Phytopathol. 1974;64:1465-1467. DOI: 10.1094/Phyto-64-1465.

17. Miller JF, Gulya TJ. Registration of DM-2 and DM-3 sunflower germplasm. Crop Sci. 1985;25(4):718-719.

18. Miller JF,Gulya TJ.Registration of six downy mildew resistant sunflower germplasm lines. Crop Sci. 1988;28(6):10401041. DOI: $10.2135 /$ cropsci1988.0011183X002800060073x.

19. Gulya TJ, Sackstone WE, Viranyi F, Masirevic S, Rashid KY. 
New races of the sunflower downy mildew pathogen (Plasmopara halstedii) in Europe and North America. J Phytopathol. 1991;32(4):303-311. DOI: 10.1111/j.14390434.1991.tb00125.x.

20. Mulpuri S, Liu Z, Feng J, GulyaTJ Jan CC. Inheritance and molecular mapping of a downy mildew resistance gene, P1 (13) in cultivated sunflower (Helianthus annuus L.). Theor Appl Genet. 2009;119(5):795-803. DOI:10.1007/s00122-0091089-z.

21. Slabaugh MB, Yu JK, Tang S, Heesacker A, Hu X, Lu G,Bidney D, Han F, Knapp SJ. Haplotyping and mapping a large cluster of downy mildew resistance gene candidates in sunflower using multilocus intron fragment length polymorphisms. Plant Biotech J. 2003;1(3):167-185. DOI: 10.1046/j.1467-7652.2003.00016.x.

22. Radwan O, Mouzeyar S, Nicolas P, Bouzidi MF. Induction of a sunflower CC-NBS-LRR resistance gene analogue during incompatible interaction with Plasmopara halstedii. J Exp Bot. 2005;56(412):567-575. DOI: 10.1093/jxb/eri030.

23. Bouzidi MF, Badaoui S, Cambon F, Vear F, De Labrouhe DT, Nicolas P, Mouzeyar S. Molecular analysis of a major locus for resistance to downy mildew in sunflower with specific PCR-based markers. Theor Appl Genet. 2002;104(4):592600. DOI: 10.1007/s00122-001-0790-3.

24. Pankovic D, Radovanovic N, Jocic S, Satovic Z, KoricDS. Development of co-dominant amplified polymorphic sequence markers for resistance of sunflower to downy mildew race 730. Plant Breed. 2007;126(4):440-444. DOI: 10.1111/j.1439-0523.2007.01376.x.

25. Gedil MA, Slabaugh M.B, Berry S, Johnson R, Michelmore R, Miller J, Gulya T, Knapp SJ. Candidate disease resistance genes in sunflower cloned using conserved nucleotide-binding site motifs: genetic mapping and linkage to the downy mildew resistance gene $P l_{1}$. Genome. 2001;44(2):205-212.

26. Shapouran F, Ghoosta Y, Hemmati R, Rahmanpour S, Darvishzadeh R. Identification of physiological races of Plasmopara halestedii, the causal agent of sunflower downy mildewin Urmia. Plant Protec. 2012;35(2):41-51(Farsi).

27. Rahmanpuor S. Seed and Plant Improvement Research Institute, Iran. Personal communications. 2013.

28. Li JT, Yang J, Chen DC, Zhang XL, Tang ZS. An optimized mini-preparation method to obtain high-quality genomic DNA from mature leaves of sunflower. Genet Mol Res. 2007;6(4):1064-1071.

29. Collard BC,Mackill DJ. Marker-assisted selection: an approach for precision plant breeding in the twenty-first century. PhilosTrans R SocLond B Biol Sci. 2008;363(1491):557-572.

30. James CM, Clarke JB, Evans KM. Identification of molecular markers linked to the mildew resistance gene Pl-d in apple. Theor Appl Genet.2004;110(1):175-181.

31. Boersma JG, Pallotta M, Li C, Buirchell BJ, Sivasithamparam $\mathrm{K}$, Yang $\mathrm{H}$. Construction of a genetic linkage map using MFLP and identification of molecular markers linked to domestication genes in narrow-leafed lupin (Lupinus angustifolius L.). Cell Mov Biol Lett. 2005;10(2):331-344.

32. Gupta SK, Charpe A, Prabhu KV, Haque QM. Identification and validation of molecular markers linked to the leaf rust resistance gene Lr19 in wheat. Theor Appl Genet.
2006;113(6):1027-1036. DOI: 10.1007/s00122-006-0362-7.

33. Gordon SG, Kowitwanich K, Pipatpongpinyo W, St Martin SK, Dorrance AE. Molecular marker analysis of soybean plant introductions with resistance to Phytophthora sojae. Phytopathol. 2007;97(1):113-118. DOI: 10.1094/PHYTO-970113.

34. Bipinraj A, Honrao B, Prashar M, Bhardwaj S, RaoS, Tamhankar S. Validation and identification of molecular markers linked to the leaf rust resistance gene $L r 28$ in wheat. J Appl Genet. 2011;52(2):171-175. DOI: 10.1007/s 13353-010-0026-9.

35. Kim S, Song YH, Lee JY, Choi SR, Dhandapani V, Jang CS, Lim YP, Han T. Identification of the BrRHP1 locus that confers resistance to downy mildew in Chinese cabbage (Brassica rapa ssp. pekinensis) and development of linked molecular markers. Theor Appl Genet. 2011;123(7):11831192. DOI: 10.1007/s00122-011-1658-9.

36. Zhao B, Deng QM, Zhang QJ, Li JQ, Ye SP, Liang YS, Peng Y, Li P. Analysis of segregation distortion of molecular markers in $\mathrm{F}_{2}$ population of rice. Acta Genetic Sinica. 2006;33(5):449-457. DOI: 10.1016/S0379-4172(06)60072-3.

37. Cai J, Zhang X, Wang B, Yan M, Qi Y, Kong L. A genetic analysis of segregation distortion revealed by molecular markers in Lophopyrum ponticum chromosome 7E. J Genet. 2011;90(2):373-376. 